\title{
ANALISIS INTEGRASI KEISLAMAN PADA MATERI KIMIA PANGAN (Sumber, Manfaat, dan Keterpahamannya)
}

\author{
Gaosiatul Chasanah $^{\mathbf{1}^{*}, \text { Siti Suryaningsih }}{ }^{\mathbf{1}}$ dan Dila Fairusi ${ }^{\mathbf{1}}$ \\ ${ }^{7}$ Program Studi Pendidikan Kimia, Fakultas Ilmu Tarbiyah dan Keguruan, \\ Universitas Islam Negeri Syarif HIdayatullah Jakarta, Indonesia \\ *E-mail: gaosiatul.chasanah12@mhs.uinjkt.ac.id
}

\begin{abstract}
ABSTRAK
Integrasi antara sains dengan Alquran menjadi topik yang terus berkembang di kalangan cendekiawan. Pembahasan mengenai dikotomi antara Alquran dan sains terus diperbincangkan. Beberapa cendekiawan menyatakan adanya hubungan erat antara sains dan islam. UIN Syarif Hidayatullah Jakarta sebagai transformasi dari Institut Agama Islam Negeri (IAIN) tidak dapat dipisahkan dari harapan pengintegrasian ilmu pengetahuan, salah satunya integrasi dengan keislaman. Implementasi integrasi keislaman perlu diterapkan dalam seluruh mata kuliah kimia. Penelitian ini bertujuan untuk menganalisis konten sains yang terintegrasi keislaman pada mata kuliah kimia pangan serta menguji keterpahaman konten tersebut. Metode yang digunakan adalah metode Four Steps Teaching Material Development (4 STMD) yang terdiri dari empat tahap, yaitu seleksi, strukturisasi, karakterisasi, dan reduksi. Penilaian yang dilakukan berupa validasi konten oleh ahli integrasi keislaman dan uji keterpahaman konten oleh 59 mahasiswa pendidikan kimia semester V. Hasil validasi materi diolah dengan menggunakan skala Guttman dan hasil uji keterpahaman diinterpretasikan berdasarkan kategori keterpaham teks menurut Rankin dan Culhane. Hasil validasi ahli didapatkan kumpulan konten kimia pangan valid dan layak digunakan, kemudian hasil uji keterpahaman konten didapatkan kategori tinggi sebesar 90\% dengan kriteria konten mudah untuk dipahami. Berdasarkan hasil penelitian yang dilakukan didapatkan 10 indikator dengan tiga konsep utama yaitu karbohidrat, protein, dan lipid dengan aspek keislaman fokus pada ayat qauliyah (Alquran dan Hadits).
\end{abstract}

Kata Kunci: integrasi, keislaman, keterpahaman, kimia pangan, visi

\begin{abstract}
The integration of science with Alquran is a topic that considered to continues among scholars. Discussion of the dichotomy between Alquran and science continues to be discussed. Some scholars say there is a close relationship between science and Islam. UIN as a transformation from the State Islamic Institute (IAIN) is inseparable from the hopes of integrating science, one of which is integration with Islam. The implementation of Islamic integration needs to be applied in all chemistry classes. This study aims to analyze scientific content integrated with Islam in the food chemistry course and test the understanding of the content. The method used is the Four Steps Teaching Material Development method (4 STMD) which consists of four steps: selection, structuring characterization, and reduction. The assessment was validated by Islamic integration experts and content comprehension test by 59 semester chemistry education students. Data analysis techniques in content validation using the Guttman scale and the results of understanding tests are interpreted based on the category of text comprehension according to Rankin and Culhane. The results of expert validation obtained a valid and feasible food chemical content, for the results of the content understanding test found a high category of $90 \%$ with easy conte nt criteria. Based on the results of the research, obtained 10 indicators with 3 main concepts, which is carbohydrates, proteins, and lipids with Islamic aspects focusing on the verse Qauliyah (Qur'an and Hadith)
\end{abstract}

Keywords: integration, islamic, understanding, food chemistry, vision 


\section{PENDAHULUAN}

Pembahasan mengenai dikotomi antara alquran dan sains terus diperbincangkan (Turgut, 2016). Beberapa cendekiawan menyatakan melalui ayat-ayat dalam Alquran, dapat dilihat adanya hubungan erat antara sains dan Islam (Munadi, 2016; Bagheri dkk., 2015). Integrasi keislaman sendiri telah diterapkan pada sistem pendidikan beberapa negara seperti, Brunei Darussalam, Malaysia, Mesir, dan Yaman (Al-Hadabi, 2016; Bagheri dkk., 2015; Lubis, 2015; Lubis dkk., 2009; Zain dkk., 2016). Di Indonesia, yaitu UIN Syarif Hidayatullah Jakarta, sebagai transformasi dari Institut Agama Islam Negeri (IAIN) tidak dapat dipisahkan dari harapan pengintegrasian ilmu pengetahuan, termasuk integrasi dengan keislaman. Dengan cita-cita inilah kemudian Universitas Islam Negeri (UIN) Syarif Hidayatullah Jakarta mengambil langkah menjadikan integrasi keislaman sebagai visi universitas, guna menghasilkan lulusan yang cerdas secara intelektual dan spiritual.

Berdasarkan pedoman integrasi ilmu UIN Syarif Hidayatullah Jakarta yang termuat dalam Surat Keputusan Rektor UIN Syarif Hidayatullah Jakarta Nomor 864 Tahun 2017 tentang Pedoman Integrasi IImu pada UIN Syarif Hidayatullah Jakarta, Program Studi Pendidikan Kimia mengambil langkah untuk mengembangkan kurikulum kegiatan pembelajaran dalam rangka mengimplementasikan visi integrasi keislaman universitas. Sesuai Permenristekdikti No. 44 tahun 2015, bahwa setiap program studi diperbolehkan untuk menambah capaian pembelajaran sesuai dengan visi misi universitas untuk memberi ciri lulusan program studinya.

Integrasi keislaman pada kurikulum Pendidikan Kimia UIN Syarif Hidayatullah
Analisis Integrasi Keislaman pada Mata Kuliah Kimia Pangan (Sumber, Manfaat dan Keterpahamannya)

Jakarta telah diimplementasikan melalui mata kuliah Integrasi Nilai berupa pengintegrasian materi kimia dasar dengan keislaman. Selain sebagai upaya mewujudkan visi universitas, integrasi keilmuan juga dapat dilakukan untuk melatih mahasiswa berpikir kritis, dapat dilihat dari kemampuan dalam mengkaji sumbersumber sains dan sumber-sumber keislaman. Selain itu, dapat dijadikan sebagai terobosan materi pembelajaran yang inovatif guna mendukung pendidikan Islam yang berkualitas. Oleh karena itu, integrasi keislaman perlu diterapkan ke dalam seluruh mata kuliah kimia demi tercapainya visi UIN Syarif Hidayatullah Jakarta tersebut, salah satunya kimia pangan.

Kimia Pangan sebagai salah satu cabang ilmu kimia membahas perubahan yang terjadi pada makanan selama produksi, pengolahan, penyimpanan dan memasak, tidak hanya membahas elusidasi komposisi bahan baku dan produk akhir. Kimia pangan melalui materi kandungan kimia pada bahan pangan, memberikan pengetahuan tentang kriteria mengenai pangan yang baik dan aman untuk dikonsumsi yang kemudian lebih dikenal dengan sebutan nutrisi. Nutrisi terdiri dari beberapa komponen di antaranya karbohidrat, protein, lemak, air, vitamin, dan mineral. Pada artikel ini peneliti akan membahas integrasi keislaman hanya pada tiga konsep yaitu karbohidrat, protein, dan lemak atau minyak serta menganalisis keterpahaman mahasiswa terhadap konsepkonsep yang diintegrasikan. Komponen nutrisi yang berperan sebagai sumber tenaga adalah karbohidrat, protein dan lemak. Tiga komponen ini banyak disebutkan sumber pangannya dalam Alquran. Seperti padipadian, kurma, daging, dan ikan. Selain itu, ketiga komponen ini juga telah dipelajari di jenjang Madrasah Aliyah, sehingga dapat 

Keterpahamannya)

diaplikasikan dalam penyampaian materi Sains Madrasah, khususnya mata pelajaran Kimia.

Integrasi keislaman yang dimaksud pada penelitian ini adalah upaya untuk menyatukan wahyu Tuhan dan temuan pikiran manusia, dengan tidak mengesampingkan Tuhan atau sering kita sebut sekuler dan tidak mengisolasi manusia (asketisme duniawi lainnya) (Munadi, 2016). Sesuai dengan pandangan islam mengenai hubungan konsep Tuhan dengankonsep ilmu yang tidak dapat dipisahkan karena semua ilmu berasal dariNya. Integrasi keislaman dan ilmu pengetahuan berarti menggabungkan ilmu pengetahuan umum dengan agama menjadi satu kesatuan yang utuh dengan merujuk pada Alquran dan hadis. Hal ini jelas disebutkan dalam Q.S Al-kahfi ayat 109 bahwa ilmu-Nya absolut dan menyeluruh. Oleh karena seluruh ilmu berasal dari Tuhan, maka proses pencarian, penerapan, dan penyebarannya harus sesuai dengan kehendak-Nya (Masruri, 2007). Adapun model integrasi yang digunakan adalah model Diadik Dialogis menurut Bagir (2005). Model ini diilustrasikan melalui diagram dengan dua buah lingkaran sama besar yang saling berpotongan. Jika dua diagram itu mencerminkan sains dan agama akan terdapat sebuah kesamaan yang dicerminkan melalui area yang berpotongan. Kesamaan itulah yang merupakan dialog antara sains dan agama. Sebagai contoh, islam mewajibkan umat muslim untuk mengonsumsi makan yang halal dan baik. Kemudian dalam ilmu kimia pangan dijelaskan bahwa makanan yang baik adalah makanan yang mengandung nutrisi, bergizi, dan baik untuk kesehatan (Minarno dkk., 2008). Melalui penggambaran kecil ini, sudah dapat kita lihat bahwa antara sains dan islam terdapat kesamaan.

\section{METODE PENELITIAN}

Metode yang digunakan pada penelitian ini adalah Research and Development dengan model Four Steps Teaching Material Development (4S-TMD). Model ini terdiri dari empat tahap, yaitu tahap seleksi, strukturisasi, karakterisasi dan reduksi.

Tahap seleksi merupakan kajian kepustakaan untuk mengumpulkan informasi berkaitan dengan materi yang akan dianalisis seperti studi sumber bahan ajar dan lainnya. Kegiatan yang dilakukan meliputi: (1) mengembangkan indikator materi terintegrasi; (2) menganalisis konsep sesuai dengan indikator yang dikembangkan; (3) mengumpulkan sumber referensi; (4) menganalisis integrasi keislaman yang dapat dilakukan pada materi yang telah ditentukan; (5) validasi oleh ahli guna menjamin keabsahan dan keakuratan konten yang diintegrasikan. Agar didapatkan jawaban yang tegas dan konsisten, hasil validasi diolah dengan menggunakan skala Guttman dengan alternatif jawaban Ya dan Tidak. Adapun skor akhir diinterpretasikan berdasarkan rumus berikut:

$$
\text { Persentase }=\frac{\text { Skor Total }}{\text { Skor Maksimal }} \times 100 \%
$$

Tahap strukturisasi merupakan tahap menstruktur materi tahap seleksi secara didaktis agar materi dapat lebih mudah dipahami. Tahap strukturisasi meliputi (1) membuat peta konsep; (2) membuat struktur makro; dan (3) menyesuaikan struktur konsep yang dianalisis; (4) review ahli (peta konsep, dan struktur makro) untuk melihat ketepatan penyusunan materi.

Tahap karakterisasi, merupakan tahap yang dilakukan untuk mengidentifikasi karakter konsep menggunakan penulisan ide pokok yang telah dikembangkan oleh Sjaeful Anwar 
Kimia Pangan (Sumber, Manfaat dan Keterpahamannya)

(Hendri dan Setiawan, 2016; Arifin dan Sajeful, 2016). Dalam memahami suatu teks perlu pemahaman yang utuh, oleh karena itu, digunakan instrumen penulisan ide pokok. Dengan kata lain melalui penulisan ide pokok mahasiswa akan menemukan gagasan yang tertuang dari sebuah teks melalui tahapan berpikir. Pada tahap ini mahasiswa kemudian dituntut untuk berpikir kritis mengenai konsep yang telah diintegrasikan. Data keterpahaman dianalisis dengan menggunakan rumus berikut (Arifin dan Sjaeful, 2016):

$$
K=\frac{J b}{S} \times 100 \%
$$

dengan:

$\mathrm{K}=$ Tingkat pemahaman

$\mathrm{Jb}=$ Jawaban benar

$\mathrm{S}=$ Jumlah responden

Jumlah responden pada tahap ini ditentukan dengan metode purposive sampling sebanyak 56 mahasiswa pendidikan kimia angakatan 2016/2017. Adapun kriteria tingkat kesulitan berdasarkan responden yang menjawab ide pokok dengan benar dapat dilihat pada Tabel 1.

\section{Tabel 1. Tabel Kriteria Tingkat Kesulitan menurut Berdasarkan Responden Yang Menjawab Ide Pokok Dengan Benar}

\begin{tabular}{|c|c|}
\hline $\begin{array}{c}\text { Persentase } \\
\text { jawaban } \\
\text { benar }\end{array}$ & Tingkat Keterpahaman \\
\hline $\begin{array}{c}60<\mathrm{K} \leq \\
100 \%\end{array}$ & Tinggi (Kategori Mandiri) \\
\hline $\begin{array}{c}40<\mathrm{K} \leq \\
60 \%\end{array}$ & Sedang (Kategori Instruksional) \\
\hline $\mathrm{K} \leq 40 \%$ & Rendah (Kategori Rendah) \\
\hline
\end{tabular}

(Rankin dan Culhane dalam Arifin dan Sjaeful, 2016)

Konsep-konsep yang sulit selanjutnya direduksi secara didaktis pada tahap reduksi.
Proses reduksi dapat dilakukan jika konsep yang dianalisis memiliki kategori sulit berdasarkan hasil karakterisasi.

Hasil akhir dari keempat proses pengembangan metode Four Step Materials Teaching Development berupa kumpulan konsep kimia pangan terintegrasi keislaman dengan kategori mudah dipahami.

Objek penelitian ini adalah materi kimia pangan terintegrasi keislaman berupa kumpulan konsep-konsep kimia pangan yang dikembangkan dengan mengintegrasikan dengan konten keislaman. Adapun, subjek dalam penelitian adalah dua ahli tafsir, dua dosen ahli materi, dan 56 mahasiswa pendidikan kimia angkatan 2016/2017.

Data yang diperoleh dalam penelitian ini terdiri dari dua jenis, yaitu data kuantitatif dan data kualitatif. Data kualitatif berupa: 1) Hasil validasi Ahli pada Kumpulan Materi Seleksi; 2) Hasil validasi Ahli pada kumpulan materi strukturisasi; Data kuantitatif berupa jumlah jawaban benar responden pada tahap identifikasi konsep sulit.

\section{HASIL DAN PEMBAHASAN}

Analisis kimia pangan yang terintegrasi keislaman pada materi karbohidrat, protein dan lipid, melalui beberapa tahap. Pada tahap awal yaitu tahap seleksi dilakukan pengembangan indikator berdasarkan capaian pembelajaran kimia pangan yang telah ada yang difokuskan pada aspek sumber dan manfaat bahan pangan. Konsep-konsep yang telah dipilih kemudian dianalisis dengan mengidentifikasi karakter konsep yang meliputi label konsep, definisi konsep, atribut konsep, hierarki konsep, contoh dan noncontoh berdasarkan analisis konsep menurut Herron et al. (1977). Sumber referensi utama 

Keterpahamannya)

yang digunakan pada analisis ini adalah beberapa buku teks kimia pangan universitas di antaranya, Kimia Pangan: Komponen Makro, Kimia Pangan Edisi I., Kimia Pangan dan Gizi (Winarno, 1992). Selain tiga sumber utama diatas digunakan beberapa tafsir sebagai sumber referensi integrasi keislaman di antaranya, Tafsir Ilmi, Tafsir Ibnu Katsir, Tafsir Al-Qurthubi, Tafsir Al-Misbah, dan kitabkitab hadits shohih Bukhori-Muslim. Pada tahap ini juga digunakan sumber-sumber lain dari internet, sebagian besar sebagai sumber informasi tambahan. Sesuai dengan pedoman integrasi pasal 10 tentang Integrasi Rumpun Ilmu-IImu Kealaman khususnya ayat 8 yang berbunyi bahwa integrasi ilmu dapat dilakukan dengan mencari hubungan dan titik temu antara ilmu alam dan teks Alquran dan Hadits, integrasi keislaman pada tiap-tiap konsep dilakukan dengan menghubungkan dengan ayat Qauliyah atau Alquran dan Hadits.

Kumpulan materi yang telah dianalisis dan diintegrasikan dengan keislaman kemudian divalidasi. Hasil validasi dapat disimpulkan bahwa: a) konsep yang diintegrasikan sudah sesuai; b) ayat dan tafsir yang digunakan sudah sesuai; dan c) beberapa bagian perlu ditambahkan seperti pada sanad hadits yang belum lengkap. Berdasarkan hasil tersebut, kemudian peneliti melengkapi dan menyempurnakan draf awal konsep yang telah diintegrasikan sesuai dengan saran validator. Analisis integrasi keislaman dan kimia pangan hasil validasi ahli pada materi sumber karbohidrat, protein, dapat dilihat pada Tabel 2

Tabel 2. Tabel Analisis Integrasi Keislaman dan Kimia Pangan Hasil Validasi (sumber karbohidrat dan protein)

\begin{tabular}{|c|c|c|c|}
\hline Materi & indikator & Sumber & Integrasi keislaman \\
\hline \multirow{3}{*}{ Karbohidrat } & $\begin{array}{l}\text { Memahami sumber } \\
\text { Karbohidrat } \\
\text { berdasarkan Alquran } \\
\text { surah Al-an'am ayat } 95\end{array}$ & Serealia & $\begin{array}{l}\text { Sumber karbohidrat berupa bahan pagan nabati } \\
\text { sebagian besar berasal dari tumbuhan serealia seperti } \\
\text { yang disebutkan pada surah Al-an'am ayat } 95 \text {. }\end{array}$ \\
\hline & $\begin{array}{l}\text { Memahami sumber } \\
\text { karbohidrat } \\
\text { berdasarkan Hadits } \\
\text { Riwayat Imam Muslim } \\
\text { No. } 3046\end{array}$ & Kurma & $\begin{array}{l}\text { Kurma mengandung } 70,6 \% \text { karbohidrat. Gula pada } \\
\text { kurma mudah dicerna sehingga disarankan untuk } \\
\text { berbuka puasa. Dalam hadits disebutkan bahwa "tidak } \\
\text { akan lapar keluarga yang memiliki kurma". Maksudnya } \\
\text { adalah bahwa kurma dapat dijadikan alternatif untuk } \\
\text { memenuhi kebutuhan karbohidrat bagi tubuh. }\end{array}$ \\
\hline & $\begin{array}{l}\text { Memahami sumber } \\
\text { karbohidrat } \\
\text { berdasarkan Hadits } \\
\text { Riwayat Imam Bukhari } \\
\text { No. } 4984\end{array}$ & Gandum & $\begin{array}{l}\text { Gandum disebutkan dalam hadits riwayat Imam Bukhari } \\
\text { sebagai makanan yang sehat dan tidak mengandung } \\
\text { lemak yang "jahat" di dalamnya. Hal ini sesuai dengan } \\
\text { kajian ilmiah bahwa gandum memililiki kandungan } \\
\text { nutrisi yang baik bagi tubuh. }\end{array}$ \\
\hline Protein & $\begin{array}{l}\text { Memahami sumber } \\
\text { protein berdasarkan } \\
\text { Alquran surah Al- } \\
\text { Mukmin ayat } 79 \text { dan } \\
\text { Albaqarah ayat } 61\end{array}$ & $\begin{array}{l}\text { Protein } \\
\text { hewani }\end{array}$ & $\begin{array}{l}\text { Allah menyebutkan sumber-sumber protein dalam surah } \\
\text { Al-Mukmin ayat } 79 \text { dan Albaqarah ayat } 61 \text { khusunya } \\
\text { sumber protein hewani. }\end{array}$ \\
\hline
\end{tabular}


Analisis integrasi keislaman dan kimia pangan hasil validasi ahli pada materi manfaat karbohidrat, protein, dapat dilihat pada Tabel 3.

Tabel 3. Tabel Analisis Integrasi Keislaman dan Kimia Pangan Hasil Validasi(manfaat karbohidrat, protein, dan lipid)

\begin{tabular}{|c|c|c|c|}
\hline Materi & indikator & Sumber & Integrasi keislaman \\
\hline \multirow[t]{2}{*}{ Karbohidrat } & $\begin{array}{l}\text { Menghubungkan kisah } \\
\text { Siti Maryam dengan } \\
\text { Kurma sebagai sumber } \\
\text { karbohidrat } \\
\text { berdasarkan Alquran } \\
\text { Surah Maryam ayat } 25\end{array}$ & Kurma & $\begin{array}{l}\text { Allah mengutus Jibril kepada Siti Maryam ketika } \\
\text { melahirkan Nabi Isa as. Siti Maryam diperintahkan agar } \\
\text { menggoyangkan pangkal pohon kurma sehingga akan } \\
\text { dijatuhkan kurma yang matang untuknya. Jika dikaji hal } \\
\text { ini menunjukkan bahwa kurma yang memiliki banyak } \\
\text { nutrisi dapat bermanfaat bagi tubuh seorang ibu dalam } \\
\text { proses pemulihan pasca melahirkan. }\end{array}$ \\
\hline & $\begin{array}{c}\text { Memahami manfaat } \\
\text { madu berdasarkan } \\
\text { Alquran surah An-Nahl } \\
\text { ayat } 68-69\end{array}$ & Madu & $\begin{array}{l}\text { Madu memiliki banyak manfaat tidak hanya sebagai } \\
\text { bahan makanan dan minuman, madu juga dapat } \\
\text { dijadikan obat sebagaimana yang tertuang dalam surah } \\
\text { An-Nahl ayat } 68-69 \text {. }\end{array}$ \\
\hline \multirow[b]{2}{*}{ Protein } & $\begin{array}{l}\text { Mengaitkan } \\
\text { manfaat dari sumber } \\
\text { protein dengan } \\
\text { kemurahan Allah swt. }\end{array}$ & Daging & $\begin{array}{l}\text { Daging memiliki banyak manfaat karena mengandung } \\
\text { banyak nutrisi terutama protein hal ini disebutkan dalam } \\
\text { surah Yasin ayat } 71-73 \text { bahwa manusia dapat } \\
\text { memperoleh manfaat-manfaat dari daging. }\end{array}$ \\
\hline & $\begin{array}{l}\text { Mengaitkan manfaat } \\
\text { susu sebagai sumber } \\
\text { protein dengan } \\
\text { Kemahakuasaan Allah } \\
\text { SWT. }\end{array}$ & Susu & $\begin{array}{l}\text { Susu memiliki banyak manfaat dan sangat bergizi, } \\
\text { padahal susu berasal dari perut binatang yang } \\
\text { dikeluarkan antara kotoran dan darah binatang } \\
\text { tersebut. Akan tetapi, Allah SWT. yang Maha Kuasa } \\
\text { dapat memisahkan susu dari kotoran dan darah } \\
\text { binatang tersebut tanpa mengotori susu yang } \\
\text { dihasilkan. Seperti yang tertuang dalam surah Al-An-am } \\
\text { ayat } 66\end{array}$ \\
\hline \multirow[t]{2}{*}{ Lipid } & $\begin{array}{l}\text { Menganalisis } \\
\text { kandungan } \\
\text { Habbatussauda dan } \\
\text { reaksi antioksidan } \\
\text { (timoquinon) } \\
\text { hubungannya dengan } \\
\text { H. R Muslim No. } 2215 \\
\end{array}$ & $\begin{array}{l}\text { Habbatu } \\
\text { ssauda' }\end{array}$ & $\begin{array}{l}\text { Dalam hadis riwayat Imam Muslim disebutkan bahwa } \\
\text { Habbatussauda' merupakan tanaman yang diberkahi. } \\
\text { Habbatussauda' dapat dijadikan obat berbagai macam } \\
\text { penyakit. Hal ini sesuai dengan kajian ilmiah bahwa } \\
\text { dalam Habbatussauda' terdapat timoquinon sebagai } \\
\text { antioksidan yang aktif menangkal radikal bebas. }\end{array}$ \\
\hline & $\begin{array}{l}\text { Menghubungkan } \\
\text { manfaat dari sumber } \\
\text { lemak atau minyak } \\
\text { dengan kekuasaan } \\
\text { Allah swt. }\end{array}$ & $\begin{array}{l}\text { Minyak } \\
\text { Zaitun }\end{array}$ & $\begin{array}{l}\text { Minyak zaitun telah disebutkan dalam surah An-Nahl } \\
\text { ayat } 11 \text {, selain itu menurut surah Al-Mukminun ayat } 20 \\
\text { minyak zaitun memiliki berbagai manfaat untuk bahan } \\
\text { makanan. Dewasa ini, minyak zaitun juga banyak } \\
\text { digunakan untuk produk kecantikan. }\end{array}$ \\
\hline
\end{tabular}


Analisis Integrasi Keislaman pada Mata Kuliah Kimia Pangan (Sumber, Manfaat dan Keterpahamannya)

Pada tahap strukturisasi dihasilkan struktur makro, yang meliputi karbohidrat, protein dan lipid masing-masing memuat 2 bagian yaitu sumber bahan pangan serta manfaatnya. Adapun struktur makro dari konsep-konsep yang terintegrasi dapat dilihat pada Gambar 1.

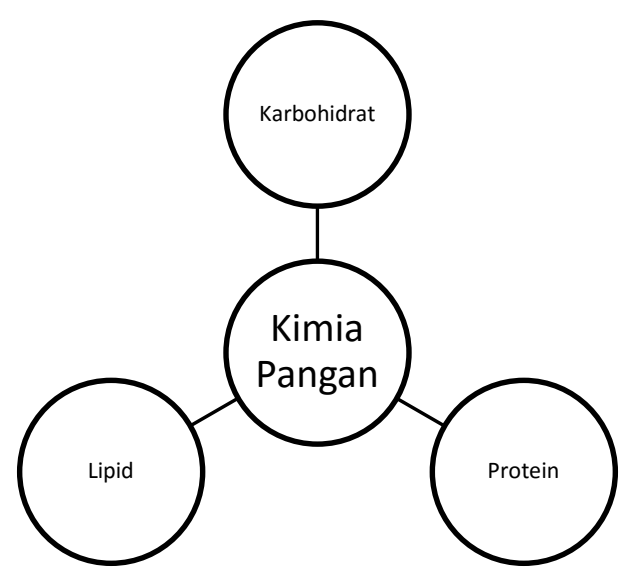

Gambar 1. Struktur Makro

Pada tahap karakterisasi selanjutnya dihasilkan persentase tingkat kesulitan dan keterpahaman teks konsep yang telah diintegrasikan, kepada 56 mahasiswa pendidikan kimia yang telah mendapatkan mata kuliah kimia pangan, dengan memberikan soal tes rumpang dari teks yang telah diintegrasikan, selanjutnya mengisi kriteria tingkat kesulitan teks, dan menuliskan ide pokok dari tiap-tiap teks konsep untuk mengetahui tingkat keterpahaman teks konsep. Mahasiswa yang memberikan kriteria sulit terhadap teks konsep disediakan kolom untuk menuliskan alasan menganggap konsep tersebut sulit. Hal ini dilakukan untuk mempermudah peneliti dalam melakukan reduksi terhadap konsep yang mendapatkan kategori sulit atau sedang pada tahap selanjutnya. Langkah serupa dilakukan dalam penelitian Arifin dan Sjaeful (2016) serta Hendri (2016). Adapun persentase hasil karakterisasi dapat dilihat pada Tabel 4.

Tabel 4. Hasil Karakterisasi

\begin{tabular}{|c|c|c|c|c|}
\hline No & Label Konsep & $\begin{array}{c}\text { Persentase } \\
\text { Keterpahaman Teks }\end{array}$ & $\begin{array}{c}\text { Tingkat Keterpahaman } \\
\text { Teks }\end{array}$ & Kriteria Teks Konsep \\
\hline 1 & Sumber Karbohidrat & 80 & Tinggi & Mudah \\
\hline 2 & Gandum & 92 & Tinggi & Mudah \\
\hline 3 & Madu & 98 & Tinggi & Mudah \\
\hline 4 & Kurma & 95 & Tinggi & Mudah \\
\hline 5 & Sumber Protein & 61 & Tinggi & Mudah \\
\hline 6 & Daging & 97 & Tinggi & Mudah \\
\hline 7 & Susu & 97 & Tinggi & Mudah \\
\hline 8 & Habbatussauda' & 95 & Tinggi & Tinggi \\
\hline 9 & Zaitun & 98 & \multicolumn{3}{|c}{90} \\
\hline \multicolumn{7}{|r}{} \\
\hline
\end{tabular}

Tahap terakhir yaitu tahap reduksi. Tahap reduksi dilakukan untuk mereduksi konsep yang masih memiliki kriteria sulit atau sedang dan mendapatkan tingkat keterpahaman yang rendah ataupun sedang (Arifin dan Sajeful, 2016). Proses reduksi dilakukan dengan menggunakan simbol, sketsa, contoh atau analogi sesuai dengan kisi-kisi reduksi yang telah dibuat (Hendri dan Setiawan, 2016). Hal ini dilakukan agar konsep yang dianalisis integrasi keislamannya dapat dengan mudah dipahami oleh pembaca. Pada penelitian ini, tahap reduksi tidak dilakukan karena seluruh konsep hasil analisis integrasi keislaman mendapatkan kriteria mudah dan tingkat keterpahaman yang tinggi dengan rata-rata 
90\%. Hal ini menunjukkan bahwa konsep yang

diintegrasikan dengan keislaman dapat dengan mudah dipahami.

\section{KESIMPULAN}

\begin{abstract}
Berdasarkan hasil penelitian dapat disimpulkan bahwa analisis integrasi keislaman pada pokok bahasan karbohidrat, protein, dan lipid menghasilkan 10 konsep terintegrasi keislaman meliputi sumber karbohidrat dan protein serta manfaat karbohidrat, protein, dan lipid berupa, gandum, kurma, madu, daging, susu, habbatussauda, dan minyak zaitun. Integrasi dilakukan dengan memfokuskan pada ayatayat Qauliyah agar lebih teruji kevalidan sumbernya. Kemudian didapatkan respon dari validator bahwa setiap konsep yang telah diintegrasikan sudah sesuai dengan konten keislaman baik dari segi isi materi maupun ayat dan hadits yang digunakan. Berdasarkan hasil tersebut dapat disimpulkan bahwa materi kimia dapat diintegrasikan dengan konten keislaman sesuai dengan visi universitas. Sehingga, dapat dilaksanakan pembelajaran sains khususnya kimia yang terintegrasi keislaman.
\end{abstract}

Berdasarkan uji karakterisasi, didapatkan hasil rata-rata $90 \%$. Hal ini menunjukkan bahwa konsep yang telah diintegrasikan memiliki kriteria mudah dengan tingkat keterpahaman yang tinggi dan layak untuk disampaikan atau dibaca oleh mahasiswa.

Penelitian ini terbatas, hanya pada mata kuliah kimia pangan dan tiga konsepnya. Perlu dilakukan studi lebih lanjut mengenai integrasi keislaman dan sains yang lebih luas, baik pada mata kuilah yang sama maupun pada mata kuliah sains lainnya. 


\section{DAFTAR PUSTAKA}

Al-Hadabi, A. S. (2016). Integrating the Qur'an verses into secondary school sciences curriculum of Yemen: An islamic perspective. Internatonal Journal of Humanities and Social Sciences Research, 2, 37-48.

Al-Qurthubi, Syaikh Imam. (2008). Al Jami' Il Ahkaam Alquran, Jilid 12. Jakarta: Pustaka Azzam.

Arifin, \& Sjaeful, A.(2016). The Development Of Air-Theme Integrated Science Teaching Material Using Four Steps Teaching Material Development. Jurnal Pendidikan Fisika Indonesia, 12(1), 8-18.

Bagheri, A., Hosseinjanzadeh, F., \& Mehr, M. S. (2015). The Consideration of Physics and Chemistry Sciences in Holy Quran. Journal of Applied Environmental and Biological Sciences, 4(12), 260-265.

Bagir, Z. A. (2005). Integrasi Ilmu dan Agama, Interpretasi dan Aksi. Bandung: Mizan.

Hendri, S., \& Setiawan, W. (2016). Pengembangan Bahan Ajar Tema Gempa Bumi Menggunakan Four Step Teaching MaterialsDevelopment. Jurnal Pendidikan Fisika Indonesia, 12(1), 65-76.

Herron, J. D., Cantu, L. L., Ward, R., \& Srinivasan, V. (1977). Problems associated with concept analysis. Science Education, 61(2), 185-199.

Lubis, M. A. (2015). Effective Implementation Of The Integrated Islamic Education. Global Journal Al-Thaqafah, 5(1), 59-68.

Lubis, M. A., Mustapha, R., \& Lampoh, A. A. (2009). Integrated Islamic Education in Brunei Darussalam: Philosophical Issues and Challenges. Journal of Islamic and Arabic Education, 1(2), 51-60.

Masruri, M. H. (2007). Filsafat Sains dalam
Analisis Integrasi Keislaman pada Mata Kuliah Kimia Pangan (Sumber, Manfaat dan Keterpahamannya)

Alquran: Melacak kerangka Dasar Integrasi Ilmu dan Agama. Malang: UIN Malang Press.

Minarno, Eko Budi dan Liliek Hariani. 2008. Gizi dan Kesehatan Perspektif Alqur'an dan Sains. Malang: UIN Malang Press.

Munadi, M. (2016). Integration of Islam and Science: Study of Two Science Pesantrens (Trensain) in Jombang and Sragen. Jurnal Pendidikan Islam, 5(2), 287-303.

Turgut, H. (2016). Pre-Service Science Teachers' Perceptions about Relationship between Religion and Science in the Context of Their Worldviews. International Jurnal of Educational Sciences, 8(3), 166-179.

Winarno, F.G. (1992). Kimia Pangan dan Gizi. Jakarta: Gramedia Pustaka Utama.

Zain, S., Ahmad, Z., Ismail, A. F., Salah, M., \& Mohamad, S. A. (2016). Development of Integrated Science Textbooks by Applying the ENRICH Tool. Journal of Education and Social Sciences, 5(10), 6-13. 